\title{
Ethicists urge funding for extraction of embryo cells
}

[WASHINGTON] A US presidential commission is poised to recommend that the government should pay not only for research on stem cells extracted from human embryos left over at infertility clinics, but also for the process of extraction.

The recommendation appears in the draft of a report that the National Bioethics Advisory Commission (NBAC) hopes to finalize at the end of June. It conflicts with current legislation that bars the government from funding research in which human embryos are destroyed or discarded.

The report is likely to inject more controversy into a heated debate. Abortion opponents and their allies on Capitol Hill are contesting a less radical position already taken by the Department of Health and Human Services. The department interprets the current law as allowing the federal funding of stemcell research, although not the extraction of the cells from embryos.

But the bioethics commission argues that both the extraction of the stem cells - which involves destroying the embryo - and research on them are "ethically acceptable for federal funding". It calls on Congress to repeal parts of the law.

"The ban conflicts with several ethical goals of medicine, especially healing, prevention and research," says the draft report. "Conservatives who accept that killing a fetus is permissible where it is necessary to save the life of the mother should agree with liberals that it is also permissible to destroy embryos where it is necessary to save people."

Thomas Murray, president of the Hastings Center, a bioethics think-tank in Garrison, New York, and a member of the commission, says its conclusions were influenced by

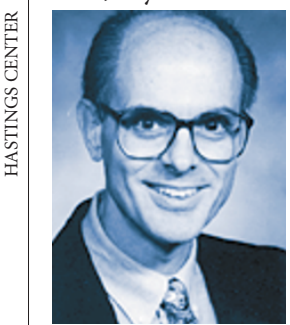

Murray: 'enormous medical potential'. the medical promise of embryonic stem cells, whose isolation was announced last November (see Nature 396, 104; 1998 \& 397, 185; 1999).

The cells are thought to have the capacity to differentiate into virtually all types of cells, possibly leading to therapies for a wide range of diseases, from Parkinson's to juvenile diabetes. According to Murray, commission members weighed this potential value against the fact that thousands of frozen embryos stored at infertility clinics are bound for destruction anyway. He says: "We are looking at research that has the potential to benefit many millions of Americans and many more people around the world."
The draft says that government-financed derivation of stem cells from aborted fetuses, already permissible under federal law, should continue. But it draws a line at the creation of embryos for the purpose of generating stem cells, citing no "compelling" reasons for the government to finance this.

It also advises that couples should not be approached to donate excess embryos more are typically created during fertility treatment than are implanted - until they have ceased fertility treatment. And it says that national and local oversight of research protocols will be "crucial".

Eric Meslin, NBAC executive director, emphasizes that the report is not final, and says that "further and intense discussions" among commissioners are still possible. But Murray says the conclusions are unlikely to be substantially changed.

The National Institutes of Health (NIH) is already finalizing guidelines in which it says its investigators will be able to conduct research on embryonic stem cells (see Nature $398,551 ; 1999)$. It is not clear what will happen when the NIH begins such funding in the face of a congressional ban whose authors, led by Congressman Jay Dickey (Republican, Arkansas), insist that it forbids stem-cell research.

Richard Doerflinger, a spokesman for the NationalConference of Catholic Bishops, says the NBAC's recommendations come as no surprise because the commissioners were appointed by President Bill Clinton, who has supported research with excess embryos. But Doerflinger says: "There are more people in Congress than on the commission that recognize the human embryo as having a right to life. So we expect a different conclusion there."

Doerflinger agrees with one NBAC conclusion, however: "They find it very unconvincing to divorce the use of the cells from their harvesting. The commission is willing to bite the bullet and have an honest debate on what the law should be."

A poll released last week indicates that three out of four Americans are willing for the government to fund stem-cell research. In a survey of 1,005 adults, 74 per cent said they favoured federal funding after having been read a statement that "researchers believe that stem cells can be developed into replacement cells to cure diseases such as diabetes, Parkinson's, Alzheimer's, cancer, heart disease" and others.

The poll was commissioned by the Patients' Coalition for Urgent Research, a group of 27 medical research and disease advocacy organizations launched last week to lobby for funding.

Meredith Wadman

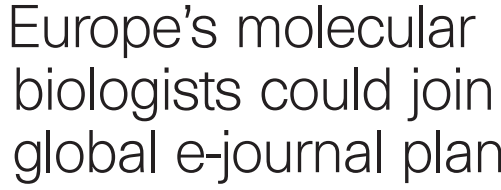

[PARIS] The European Molecular Biology Organization (EMBO) may join the initiative of the US National Institutes of Health (NIH) to launch a global website to centralize much of the biomedical literature and make it freely accessible. EMBO executive director Frank Gannon met NIH director Harold Varmus recently for talks.

The meeting may be the first step in the internationalization of the 'E-Biomed' project (see Nature 398, 735; 1999). The EMBO council is now considering the possibility of joining the NIH in an interim governing board and offering its peer-review services.

Some observers predict that, if such a board can attract the major stakeholders, it would be sufficient to get the initiative under way. That would avoid the need for an international consultation that might see the project derailed by publishers and professional societies with interests in maintaining the current print journals system.

Separate plans to establish a preprint server in biomedicine are already being discussed by the British Medical Journal and HighWire Press, a not-for-profit outfit set up in 1995 by Stanford University Libraries and Academic Information Resources to help universities and societies publish on the web at low cost.

"I think we are going to go forward anyway [despite 'E-Biomed'] on the grounds that a thousand flowers may bloom," says Michael Keller, head of HighWire Press. "At some point there will be a collapse into one or several servers," he predicts.

Richard Horton, editor of The Lancet medical journal, says that he is in principle ready to support Varmus's proposal. "I find 'E-Biomed' a very welcome stimulus for debate. I'm delighted to see it," says Horton. His vision is of the bulk of the primary literature being freely accessible, with only the top journals surviving as commercial enterprises.

But Horton is concerned that the proposed global database may accentuate the Anglo-Saxon domination of publishing, and result in discrimination against scientists from non-English-speaking, and developing, countries.

Vitek Tracz, chief executive officer of the Current Science group, says his company will also launch a preprint server (with optional peer review) this summer. The company has decided to offer all primary papers in medicine and biology free online, and to reap profits from review journals. Tracz is a keen supporter of 'E-Biomed', and is discussing how his company could participate. Declan Butler 